\title{
Long-run Determinants of Private Saving Behaviour in Pakistan
}

\author{
AASIM M. HUSAIN
}

\section{INTRODUCTION}

Compared to the rapidly-growing economies of Southeast Asia, the growth performance of the Pakistan economy was significantly weaker during the 1970s and 1980s. While the Southeast Asian countries made substantial progress in improving living standards, the average standard of living, as measured by the GNP per capita, was virtually stagnant in Pakistan over this period.

Much of the difference in economic performance between Pakistan and the Southeast Asian countries is often attributed to the low rates of saving and investment in Pakistan. ${ }^{1}$ Indeed, the differences in rates of domestic investment are often attributed to the differences in rates of domestic saving. Hence, the disparity in the growth performance between Pakistan and the Southeast Asian countries over the past two decades relates to the differences in saving rates, and an understanding of the fundamental determinants of saving in Pakistan assumes critical importance.

This paper reviews trend developments in the private saving behaviour in Pakistan, and compares these trends with those seen in the Southeast Asian economies during the period since 1970. Using co-integration analysis, the long-run properties of Pakistan's saving rate are examined, with a view to identifying the main determinants of saving.

The principal finding is that about one-half of the trend increase in saving appears to be related to financial development and deepening. In contrast to the results obtained by Faruqee and Husain (1994) and Husain (1995) for the Southeast Asian countries, demographics appear not to have played an important role in determining saving behaviour in Pakistan, possibly because high rates of population growth during the past three decades resulted in a virtually unchanged demographic structure of the population.

Aasim M. Husain is Chief Economist, ABN AMRO Bank, N. V., Karachi.

Author's Note: Useful comments by Ashfaque H. Khan on an earlier draft are gratefully acknowledged. The views contained in this paper are those of the author and do not necessarily reflect those of ABN AMRO Bank, N. V. Because of space limitations, this paper provides only a broad summary of a study on private saving behaviour in Pakistan. A more detailed description of the empirical analysis and results discussed here may be found in a companion paper, Husain (1995a)

${ }^{1}$ See, for example, Haque, Husain, and Montiel (1994). 
The remainder of the paper is organised as follows: Section 2 outlines broad comparisons of saving and growth rates in Pakistan and Southeast Asia over the period 1970-92. A discussion of the potential determinants of saving is contained in Section 3. Developments in private saving and its determinants are provided in Section 4. Section 5 summarises the estimation results, while Section 6 gives the conclusions.

\section{SAVING AND GROWTH-INTERNATIONAL COMPARISONS}

The rate of private saving in Pakistan has averaged less than 17 percent of private disposable income over the past two decades, considerably lower than the developing economies in Southeast Asia (Table 1). During this period, there has been a significant shift in the relative performance of saving in Pakistan in comparison to the Southeast Asian countries.

In the early 1970s, the saving rate in Pakistan amounted to about 15 percent of private disposable income (Chart 1), roughly comparable to that in Indonesia, about 50 percent lower than in the Philippines, Singapore, and Thailand, and about half that in Malaysia. Following the civil war and the international oil price shock, the rat of private saving in Pakistan declined to about 10 percent in 1974-75.

Since that time, the saving rate has gradually increased, reaching an average of over 20 percent in recent years. This trend increase, however, was lower in Pakistan than in Indonesia and Thailand, where the private saving rate amounted to over 30 percent in recent years, and in Singapore, where saving was in excess of 40 percent of disposable income. By contrast, the saving rate in the Philippines declined during the late 1980s and early 1990s, and is presently lower than that of Pakistan.

The growth performance of these economies has mirrored developments in the rate of saving. Following a decline in real per capita disposable incomes in the early 1970s, incomes in Pakistan grew on average by about 2 percent annually in the late 1970s and early 1980s, and by 1 percent annually during the late 1980s and early 1990s (Chart 2). For the entire 1970-92 period, real per capita income growth averaged about 1 percent.

The growth performance in Southeast Asia, with the exception of the Philippines, was significantly stronger over this period. In Indonesia and Thailand, real per capita income growth averaged over 2 percent annually during 1970-92, while in Malaysia and Singapore the average annual growth rate was almost 4 percent and 6 percent, respectively. In the Philippines, growth declined from about 1 percent in the 1970s to -1 percent in the 1980s and early 1990s, roughly coinciding with the decline in saving.

\section{LONG-RUN DETERMINANTS OF SAVING}

Prior to analysing saving behaviour in Pakistan, it is useful to first review the theoretical relationships identified in the academic literature on the determinants of 


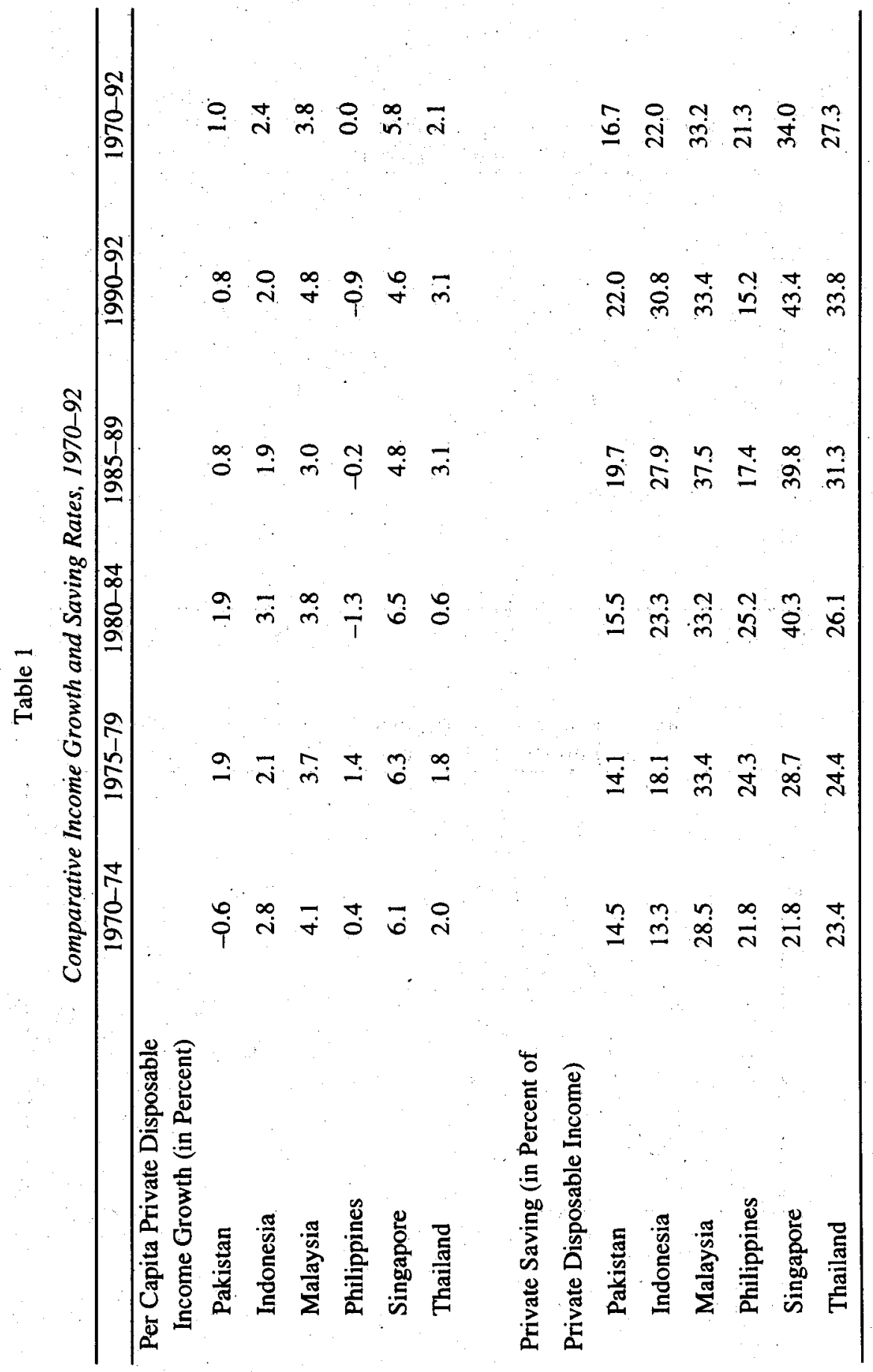


Chart 1. Private Savings, 1969-70 - $1992-93$ (in Percent of

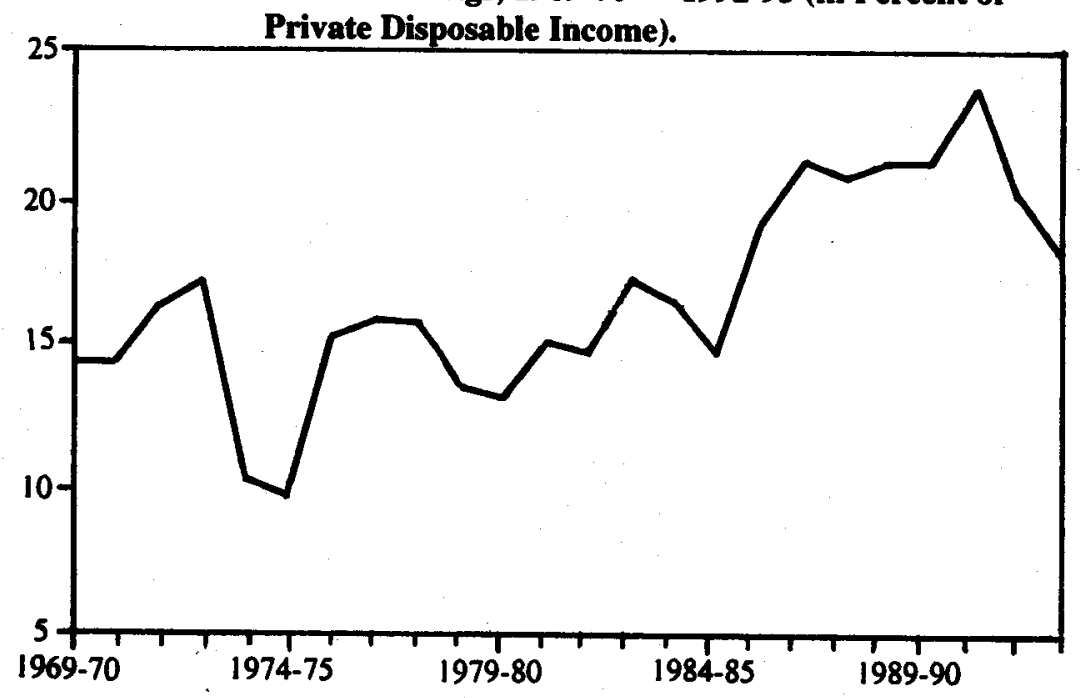

Chart 2. Real per Capita Income, 1968-69 - 1992-93

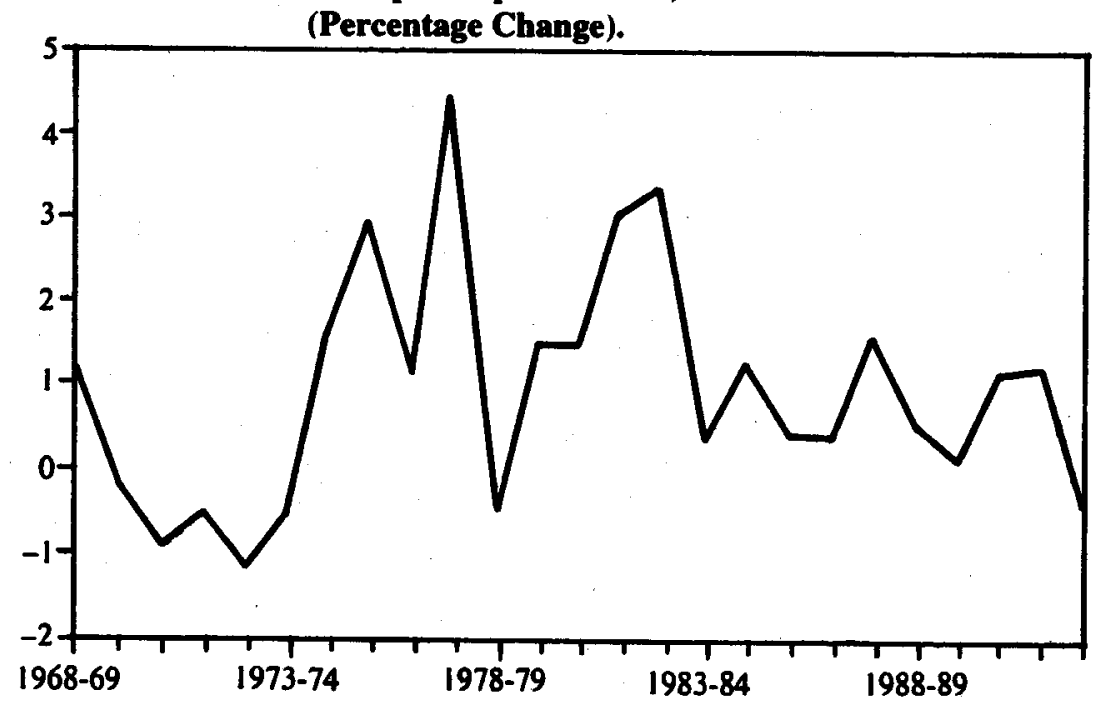


saving. Economic models of saving behaviour point to several factors that affect an economy's long-run rate of saving. For example, under the overlapping generations framework, in which individuals work and save in the first period of their lives, then retire and dissave during the second period, a principal factor influencing saving is the demographic structure of the population.

In these models, an increase in the proportion of working members of the population, by raising the ratio of savers to dissavers in the economy, is associated with an increase in the steady-state average propensity to save. Empirical evidence from both developed and developing countries has generally supported this theoretical relationship. ${ }^{2}$

Income growth can also be shown to be a determinant of the saving rate. Although an increase in the long-run (steady-state) rate of growth has no impact on the individual's saving decision, it raises saving in the aggregate by making the current period's young savers more affluent than the young savers of the previous period, who are now the older dissavers.

Empirical investigations of this relationship, however, have yielded mixed results. ${ }^{3}$ While some studies have found growth to be an important determinant of long-run saving in several countries, other studies have presented evidence indicating that changes in income growth did not have an impact on long-run developments in private saving, although differences in growth rates across countries may have accounted for inter-country differences in saving rates.

Financial development and deepening can also affect the saving performance of an economy. Financial deepening in a developing economy is associated with the increased availability of saving instruments, potentially resulting in an increase in the rate of saving. Moreover, financial development brought about by a liberalisation of financial markets would tend to raise the real rate of return on financial assets, thereby possibly also boosting the saving rate. Of course, to the extent that financial liberalisation allows an increase in borrowing by individuals who were previously constrained in their access to credit, its impact on aggregate saving could be negative.

Empirical studies of the relationship between financial development and saving have also uncovered mixed results. However, a recent study by Ogaki, Ostry, and Reinhart (1994), employing data from a large sample of developing countries, found evidence indicating that the sensitivity of the rate of saving to changes in the rate of return rises with income. Hence, to the extent that financial sector development and liberalisation is associated with higher returns, the aggregate saving rate of the economy is likely to rise as a result.

Other factors including interest rates, wealth, and public sector debt are also important determinants of the rate of saving in economic models. Their use in

${ }^{2}$ Surveys of saving trends in industrial and developing countries may be found in Dean et al. (1990) and Chandavarkar (1993), respectively.

${ }^{3}$ See, for example, Lahiri (1989) and Faruqee and Husain (1994). 
empirical work on developing countries, though, is complicated by various factors. Interest rates in many developing economies have tended to be either controlled or administered, limiting their usefulness as measures of the true cost of borrowing and lending. As regards wealth, time series data on financial, physical, and human wealth are simply not available for most developing countries. Data on public sector debt are available for most countries, but information on government assets, including real estate and state enterprises, is limited. Hence, accurate measures of net public sector debt, the variable that is important in models of saving behaviour, cannot be obtained for most developing countries.

\section{DEVELOPMENTS IN THE DETERMINANTS OF SAVING}

The next step in the analysis of saving behaviour in Pakistan consists of a review of developments in the main determinants of saving over the past two decades. Wherever possible, a summary of the developments in these determinants in the Southeast Asian economies is also described.

\section{Demographics}

Rapid population growth in Pakistan over the past two decades has resulted in virtually no change in the proportion of the population that is of working age. Indeed, despite an increase in life expectancy during this period, the working age population ratio, defined as the ratio of the population aged between 15 and 64 to the total population, declined slightly from about 52 percent in 1970 to under 51 percent in 1993 (Chart 3).

By way of comparison, the working age population ratio in the Southeast Asian countries has increased steadily over this period. In Indonesia, Malaysia, and Thailand, the proportion of the population that was of working age in 1970 was in the range of 50-55 percent, comparable to that in Pakistan. By 1992, however, the ratio was over 60 percent in each of these countries. In Singapore, the rise was even sharper, from about 58 percent in 1970 to over 70 percent by the mid 1980s.

\section{Financial Deepening}

Developments in financial deepening, as measured by the ratio of money and quasi-money to disposable income, have coincided with developments in the overall rate of private saving in Pakistan over the past 20 years. Owing to several domestic and external factors, including the division of the country in December 1971, a sharp devaluation of the rupee against the U.S. dollar in 1972, the international oil price shock in 1973-74, and the nationalisation of commercial banks in January 1975, the money to income ratio declined from about 50 percent in 1970 to under 35 percent in 1975 (Chart 4). 
Determinants of Private Saving Behaviour

1063

Chart 3. Working Age Population, 1968-69 - 1992-93 (in Percent of Total Population).

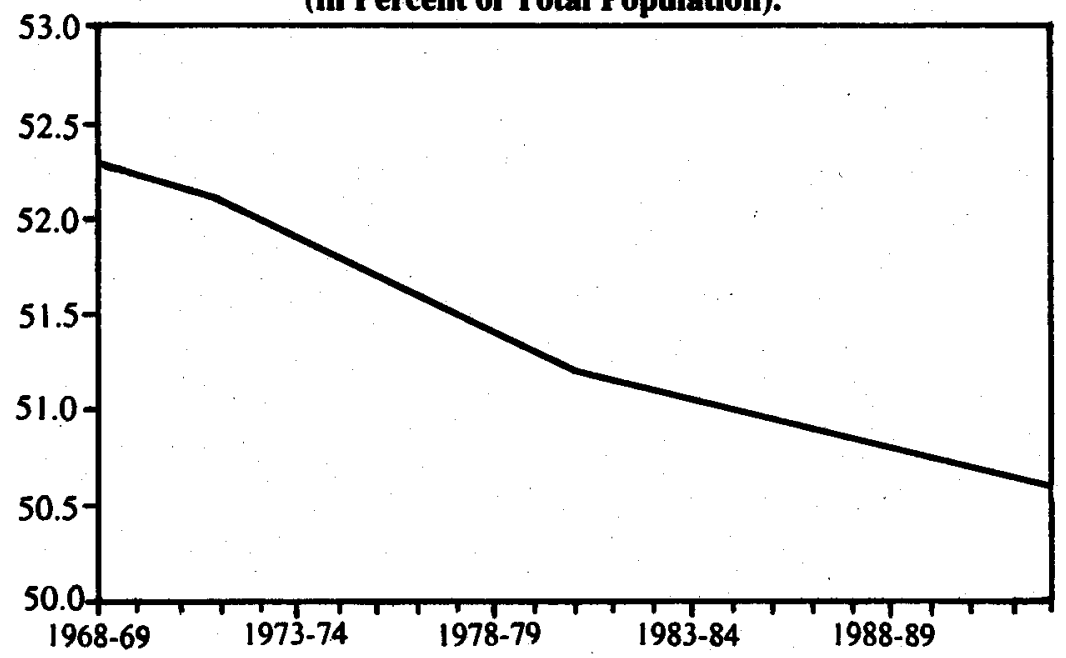

Chart 4. Money Plus Quasi-money, 1968-69 - 1992-93 (in Percent of Private Disposable Income).

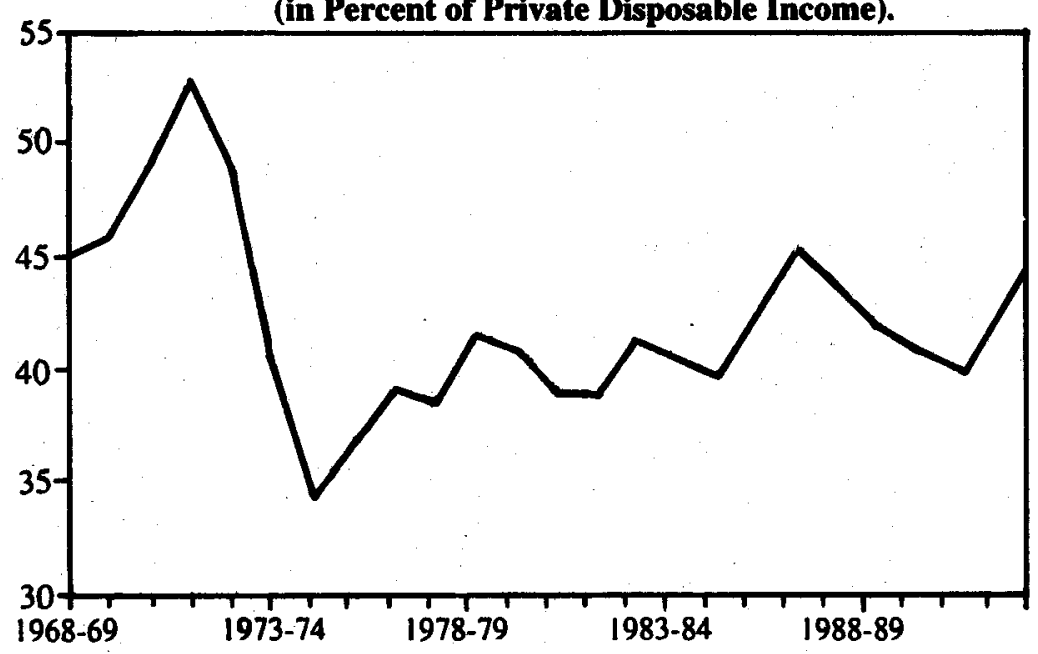


Since that time, financial deepening has progressed steadily and the money to income ratio has risen, reaching about 45 percent in recent years. Indeed, the wideranging reform and liberalisation programme embarked upon in recent years can be expected to result in a further rise in the financial ratio in the period ahead.

Comparison with the Southeast Asian countries, however, suggests that the process of financial development has been slow. In Malaysia and Thailand, the ratio of money plus quasi-money to disposable income was lower than in Pakistan in 1970, but rose sharply during the 1970s and 1980s and amounted to more than twice that of Pakistan by 1992. In Indonesia, the ratio increased from about 10 percent in 1970 to 60 percent in 1992.

\section{ESTIMATION RESULTS}

Econometric analysis, employing the co-integration methodology, was conducted using data on saving and its determinants for the period 1970-93. The results indicate that financial development was an important determinant of long-run saving in Pakistan over the past two decades. Estimates of the long-run saving equation, which is based on an economic model of saving behaviour, indicate that the private saving rate co-integrates with the financial deepening variable and the time trend.

This implies that long-run movements in the rate of private saving can be explained by long-run movements in financial development and the time trend. To the extent that variables not included in the estimations, such as net wealth and net government debt, were correlated with the time trend, the estimates appear to suggest that these variables also influenced long-run movements in the rate of saving.

The point estimate for the financial deepening variable implies that a 1 percentage point increase in the ratio of money plus quasi-money to private disposable income resulted in a long-run increase in the saving rate by 0.3 percentage point. Thus, financial development in the Pakistan economy, associated with a rising ratio of monetary assets to income, has resulted in an increase in the long-run rate of private saving by 3 percentage points, almost one half of the total increase in the trend rate of saving during the period 1975-93.

The finding that demographics did not influence the long-run saving rate in Pakistan over the past two decades is also important. While the statistical insignificance of demographics in determining long-run saving likely owes to the limited variability and change in the working age population ratio over the sample period, it may be noted that the overall increase in the saving rate was also limited during the sample period. Had shifts in the demographic structure of the population similar to those experienced in the economies of Southeast Asia also occurred in Pakistan, the increase in the rate of private saving may have been considerably sharper. 


\section{CONCLUSION}

Following a sharp decline in the early 1970s, the rate of saving by the private sector in the Pakistan economy has shown a gradual rise during the past two decades. Compared with the sharp increases recorded in the saving rates in the rapidly-growing economies of Southeast Asia, however, Pakistan's saving performance appears weak. To the extent that the high rates of saving in Southeast Asia helped finance higher rates of investment, the difference in the growth performance of that region and Pakistan may be owed to the differences in the rate of saving.

Between the mid 1970s and the early 1990s, the ratio of private saving to income in Pakistan rose by about 8 percentage points. The empirical analysis in this paper suggests that financial deepening and development accounted for about 3 percentage points of this increase. Other factors, such as wealth and public sector indebtedness, to the extent they were correlated with the time trend, may have also influenced the long-run evolution of saving, thereby accounting for the remainder of the increase.

Demographic shifts, which accounted for the bulk of the increase in saving rates in Southeast Asia, appear not to have mattered in Pakistan, mainly because the overall structure of the population remained essentially unchanged during the past two decades. Had the working age population ratio increased in Pakistan as it did in the Southeast Asian economies, and had its impact been similar to what it was in those economies, the present rate of private saving in Pakistan would have been comparable to those in the Southeast Asian countries.

\section{REFERENCES}

Chandavarkar, Anand (1993) Saving Behaviour in the Asian-Pacific Region. AsianPacific Economic Literature 7: 9-27.

Dean, Andrew, Martine Durand, John Fallon, and Peter Hoeller (1990) Saving Trends and Behaviour OECD Countries. OECD Economic Studies 14: 7-58.

Faruqee, Hamid, and Aasim M. Husain (1994) Determinants of Private Saving in Southeast Asia: A Cross-country Analysis. International Monetary Fund. (Mimeographed.)

Haque, Nadeem U., Aasim M. Husain, and Peter J. Montiel (1994) An Empirical Dependent Economy Model for Pakistan: World Development 22: 1585-1597.

Husain, Aasim M. (1995) Determinants of Private Saving in Singapore. In K. Bercuson (ed) Singapore: A Case Study in Rapid Development. International Monetary Fund. (Occasional Paper No.119.)

Husain, Aasim M. (1995a) Determinants of Private Saving in Pakistan. ABN AMRO Bank Economic Research Paper. March. 
International Monetary Fund (1993) International Financial Statistics Yearbook.

Lahiri, Ashok K. (1989) Dynamics of Asian Saving: The Role of Growth and Age Structure. International Monetary Fund Staff Papers 36: 228-261.

Ogaki, M., Jonathan Ostry, and Carmen Reinhart (1994) Financial Liberalisation, Saving, and Growth. International Monetary Fund. (Mimeographed.)

Pakistan, Government of (Various Issues) Economic Survey. 